\title{
Prevalence, co-infection and seasonality of fecal enteropathogens from diarrheic cats in the Republic of Korea (2016-2019): a retrospective study
}

\author{
Ye-In Oh${ }^{1}$, Kyoung-Won Seo ${ }^{1}$, Do-Hyung $\mathrm{Kim}^{2}$ and Doo-Sung Cheon ${ }^{3^{*}}$
}

\begin{abstract}
Background: Diarrhea is one of the most common clinical symptoms in cats and can be caused by infectious pathogens and investigation of the prevalence, co-infection and seasonality of enteropathogens are not well-established in diarrheic cats.

Results: Fecal samples of 1620 diarrheic cats were collected and enteropathogens were detected using real-time PCR. We retrospectively investigated the clinical features, total/seasonal prevalence, and infection patterns of enteropathogens. The positive infection rate was 82.59\%. Bacterial, viral, and protozoal infections accounted for 49.3, 37.57, and $13.13 \%$ of cases, respectively. Feline enteric coronavirus (FECV) was the most common pathogen (29.37\%), followed by Clostridium (C.) perfringens, Campylobacter (C.) coli, feline parvovirus, and Tritrichomonas foetus. The seasonality of enteropathogens was observed with peaks as follows: bacterial infections peaked in October, viral infections peaked in November, and protozoal infections peaked in August. Viral and protozoal infections showed differences in prevalence according to patient age. In the infection patterns, the ratios of single infections, mixed infections, and co-infections were $35.72,9.87$, and $54.41 \%$, respectively. FECV was predominant in single infections. The most common patterns of multiple infections were C. perfringens and C. coli in mixed infections and C. perfringens and FECV in co-infections.
\end{abstract}

Conclusions: Infection patterns differed according to the enteropathogen species, seasonality, and age distribution in cats. The results of this study might be helpful to understand in clinical characteristics of feline infectious diarrhea. In addition, continued monitoring of feline enteropathogens is required.

Keywords: Diarrhea, Feline, Infection, Real-time PCR

\section{Introduction}

Diarrhea is the most common clinical symptom of feline gastrointestinal diseases [1, 2]. One of the common causes of diarrhea in cats is an infection, including various bacterial, viral, protozoal, and parasitic infections

*Correspondence: dscheon@postbio.com

${ }^{3}$ Postbio Inc., Guri-si 11906, Republic of Korea

Full list of author information is available at the end of the article
$[1,3,4]$. Many pathogens have been reported to present as mixed infections, co-infections, and single infections in cats. Only one pathogen can cause diarrhea; however, several pathogens can infect a single cat simultaneously owing to shared pathogenesis with a particular pathogen or a symbiotic relationship [5]. In these cases, because of the variability of enteropathogens, treatment of patients with multiple infections is more challenging than the treatment of those with single infections, resulting in increased economic costs. Studies of infection patterns 
can help to determine a patient's treatment and prognosis. However, studies on the patterns of infection in cats with diarrhea are still limited [5-9].

Although the species and prevalence of some enteropathogens in diarrheic cats have been established, only a few studies have evaluated the relationships between specific pathogens and patient demographics or seasonality [1, 3-5, 10-12]. In humans, the relationships between various enteropathogens and other factors, such as etiology, seasonality, and age, have been studied extensively [13-17]. In addition, most feline enteropathogens have zoonotic potential, putting owners and veterinary staff at risk [11-18]. Further studies on enteropathogens in cats are needed [19-21]. Accordingly, in this study, we aimed to investigate the prevalence and infection patterns of enteropathogens in cats with diarrhea in the Republic of Korea. Additionally, we evaluated the clinical features of infections in cats, including seasonality and association with age.

\section{Materials and methods Data collection}

A retrospective study was conducted on the results of the feline diarrheal real-time PCR panel test submitted by 145 animal hospitals for 37 months from April 1, 2016, to April 30, 2019, to a commercial veterinary diagnostic laboratory (PobaniLab, Republic of Korea). All cats were patients with acute or chronic diarrhea. Clinical information, including age, breed, and sex, was obtained from animal hospitals.

\section{Sample collection and transportation}

At the animal hospitals, approximately $3-5 \mathrm{~g}$ of stool was obtained directly from the rectum or excreted feces and then placed into a sterile specimen cup. After collection, the stool samples were placed in a transport medium with a preservative and transported using a cooler bag $\left(4-10^{\circ} \mathrm{C}\right)$ to the laboratory within $2 \mathrm{~h}$. All samples were tested within $2 \mathrm{~h}$ of arrival at the PobaniLab Veterinary Diagnostic Laboratory.

\section{Molecular detection of feline enteropathogens Clinical samples}

Stool specimens were collected from cats with gastroenteritis and shipped as stool suspension in universal transport media under refrigerated conditions. For real-time PCR, $150 \mu \mathrm{l}$ of stool suspension was used for nucleic acid purification.

\section{Nucleic acid purification and real-time $P C R$}

Nucleic acids were extracted from the samples using the total nucleic acid purification kit (POSTBIO, Guri, Korea) based on the QIAcube platform (Qiagen) using a protocol tailored after the user's extraction protocol with the best optimized conditions. For real-time PCR, $5 \mu \mathrm{L}$ of nucleic acid was mixed with $20 \mu \mathrm{L}$ of master mix from Qiagen for individual targets, and qPCR or qRT-PCR was performed using an Agilent AriaMx (Agilent, Santa Clara, CA, USA). All molecular assays were performed according to the standard laboratory instructions of PobaniLab. Based on previous studies, a $C_{T}$ value of 40 or less was considered positive because there no specific $C_{T}$ values have been shown to be positive for all pathogens.

\section{Target gene and analytical sensitivity of $q P C R$ or $q R T-P C R$}

Target genes for enteropathogen detection using realtime PCR included genes from Clostridium perfringens ( $\alpha$-toxin gene, cpa) [22], Campylobacter $(C$.) coli (gyrB), C. jejuni (rimM) [23], Salmonella spp. (invE) [24], enterotoxigenic Escherichia (E.) coli (ETEC) (ST and $L T$ ), enteropathogenic E. coli (EPEC) ( $b f p A)$, enteroinvasive $E$. coli (EIEC) (ipaH), enterohemorrhagic E. coli (EHEC) (stx1 and stx2) [25], feline enteric coronavirus (FECV) (membrane protein) [26], feline parvovirus (FPV) (VP2) [27], group A rotavirus (nsp4) [25], feline immunodeficiency virus (FIV) (gag) [28], Tritrichomonas (T.) foetus (ITS-1) [29], Toxocara cati (ITS-1) [30], Toxoplasma gondii (RE) [31], Cryptosporidium parvum (18s rRNA), Giardia (G.) lamblia (18 s rRNA), Entamoeba histolytica (18s rRNA) [25], and Cyclospora (C.) cayetanensis (18s rRNA) [32]. Because the pathogenicity of Escherichia $(E$.$) coli differs$ according to the subtype [18], we tested for ETEC, EPEC, EIEC, and EHEC (Table 1).

To determine the analytical sensitivity (the lower limit of detection) for individual target genes for enteric pathogens, serial diluents ( $10^{5}$ to 1 copies/reaction) of synthetic DNAs or transcript RNAs for enteric pathogens were analyzed using qPCR or qRT-PCR. The lower limit of detection was defined as the lowest concentration that was detected in $\geq 95 \%$ of the replicates [13].

\section{Data and statistical analyses}

In this study, a mixed infection was defined as a case in which different substances from the same class, such as two types of bacterial species, were detected together, and a co-infection was indicated when different types of pathogens were detected together, e.g., bacteria and viruses, in the same fecal specimen [33].

Continuous variables, such as age, were presented as mean, minimum, and maximum values. Categorical variables were expressed as numbers and percentages. To compare the prevalence of enteropathogens according to feline age, Chi-square tests were performed. CochranArmitage tests for trends were used to assess the seasonality of the prevalence of enteropathogens. The threshold for statistical significance was set to a $P$-value of less than 
Table 1 The details of real-time PCR for the detection of feline enteropathogens

\begin{tabular}{|c|c|c|c|c|}
\hline \multirow[t]{2}{*}{ Pathogen } & \multirow[t]{2}{*}{ Target gene } & \multicolumn{3}{|c|}{ Real-time PCR conditions } \\
\hline & & PCR protocol & Primer/Probe concentration & $\begin{array}{l}\text { LOD }^{c} \\
\text { (Based on Ct 40) }\end{array}$ \\
\hline Feline coronavirus & M & RT PCR & $\begin{array}{l}\text { Primer: } 10 \text { pmole/Rx } \\
\text { Probe: } 5 \text { pmole/Rx }\end{array}$ & 10 copies \\
\hline C. perfringens & сpa & $P C R^{b}$ & $/ /$ & 100 copies/Rx \\
\hline C. coli & gyrB & $P C R$ & $/ /$ & 100 copies/Rx \\
\hline Feline parvovirus & vp2 & PCR & $/ /$ & 10 copies/Rx \\
\hline T. foetus & ITS1 & PCR & $/ /$ & 100 copies/Rx \\
\hline EPEC & bfpA & PCR & // & 100 copies/Rx \\
\hline Giardia lamblia & $18 \mathrm{~s} r \mathrm{RNA}$ & PCR & $/ /$ & 10 copies/Rx \\
\hline ETEC & ST/LT & PCR & $/ /$ & 100 copies/Rx \\
\hline C. jejuni & $\operatorname{rim} B$ & PCR & $/ /$ & 100 copies/Rx \\
\hline EHEC & stx $1 /$ st $\times 2$ & PCR & $/ /$ & 10 copies/Rx \\
\hline Group A Rotavirus & nsp4 & RT PCR & $/ /$ & 10 copies/Rx \\
\hline C.parvum & 18s rRNA & PCR & $/ /$ & 100 copies/Rx \\
\hline C. cayetanensis & 18s rRNA & PCR & $/ /$ & 100 copies/Rx \\
\hline EIEC & ipaH & PCR & $/ /$ & 100 copies/Rx \\
\hline Salmonella spp. & invE & PCR & $/ /$ & 100 copies/Rx \\
\hline E. histolytica & $18 \mathrm{~s} r \mathrm{RNA}$ & PCR & $/ /$ & 100 copies/Rx \\
\hline Toxocara cati & ITS1 & PCR & $/ /$ & 100 copies/Rx \\
\hline Toxoplasma gondii & $\mathrm{RE}$ & PCR & $/ /$ & 100 copies/Rx \\
\hline FIV & gag & $P C R$ & $/ /$ & 100 copies/Rx \\
\hline
\end{tabular}

C. perfringens Clostridium perfringens, C. coli Campylobacter coli, T. foetus Tritrichomonas foetus, EPEC enteropathogenic Escherichia coli, ETEC enterotoxigenic Escherichia coli, C. jejuni Campylobacter jejuni, EHEC enterohemorrhagic Escherichia coli, C. parvum Cryptosporidium parvum, C. cayetanensis Cyclospora cayartensis, EIEC enteroinvasive Escherichia coli, E. histolytica Entamoeba histolytica, FIV feline immunodeficiency virus

a PCR thermal condition: $95^{\circ} \mathrm{C}, 5 \mathrm{~min}\left(95^{\circ} \mathrm{C}, 10 \mathrm{~s}-60^{\circ} \mathrm{C}, 30 \mathrm{~s} ; 45 \mathrm{cycles}\right)$

${ }^{\mathrm{b}} \mathrm{RT}$ PCR thermal condition: $50^{\circ} \mathrm{C}, 15 \mathrm{~min}-95^{\circ} \mathrm{C}, 5 \mathrm{~min}\left(95^{\circ} \mathrm{C}, 10 \mathrm{~s}-60^{\circ} \mathrm{C}, 30 \mathrm{~s} ; 45 \mathrm{cycles}\right)$

${ }^{\mathrm{C}} \mathrm{LOD}$ (limitation of detection) was determined to be $10 \mathrm{folds}$ serial dilutions of synthetic plasmid including target gene of individual pathogen based on a $\mathrm{C}_{\mathrm{T}}$ value of 40

0.05. Data were analyzed using a statistical computer software (Prism 6 Version 6.01; Graphpad).

\section{Results}

\section{Clinical features of feline patients with diarrhea}

We obtained fecal samples and clinical information from 1620 cats showing symptoms of diarrhea from 145 small animal hospitals in the Republic of Korea. The number of cats per animal hospital was a minimum of 1 , a maximum of 171, and a median of 2 .

There were 32 breeds of cats represented, with 693 mixed breed cats (42.8\%) and 927 (57.2\%) pure breed cats. The most common breeds were 664 domestic shorthair cats (41\%), 100 Munchkins (6.2\%), 100 Persians (6.2\%), 96 Scottish folds (5.9\%), 88 Siameses (5.4\%), 83 Russian Blues (5.1\%), 77 Abyssinians (4.8\%), 65 Bengals (4\%), 57 Ragdolls (3.5\%), and 50 Norwegian Forests (3.1\%).

In this study, 357 male cats, 430 castrated male cats, 342 female cats, 278 spayed female cats, and 213 cats of undocumented sex were included. Due to insufficient data on sex, we did not perform a sub-analysis of sexspecific prevalence. The mean age was 3.3 years (range, 4 months to 19 years). Cats were categorized into three groups based on age as follows: < 1 year old (early age group; $n=168$ ), $1-7$ years old (middle age group; $n=1267$ ), and $>8$ years old (old age group; $n=185$ ). Among these cats, fecal real-time PCR tests of $82.59 \%$ $(1338 / 1620)$ were positive for enteropathogens.

\section{Total prevalence of feline enteropathogens}

FECV, Clostridium perfringens, C. coli, feline parvovirus (FPV), and $T$. foetus were predominant infections (Table 2). The rates of infection for bacteria, viruses, and protozoa were $49.3 \%(n=1378), 37.57 \%(n=1050)$, and $13.13 \%(n=367)$, respectively. E. coli accounted for $8.66 \%$ of the total cases, with most cases being enteropathogenic E. coli (EPEC). The top-10 most frequently detected pathogens accounted for $96.67 \%$ (2702/2795) of all cases. 
Table 2 Prevalence of enteropathogens from feline fecal specimens based on age

\begin{tabular}{|c|c|c|c|c|c|}
\hline \multirow[t]{2}{*}{ Enteropathogen } & \multirow[t]{2}{*}{ Total prevalence, $\%$ (n) } & \multicolumn{3}{|l|}{ Age } & \multirow[b]{2}{*}{$P$-value } \\
\hline & & $<1$ year & $1-7$ years & $\geq 8$ years & \\
\hline Feline coronavirus & $29.37(819)$ & $31.33(104)$ & $29(643)$ & $30(72)$ & $<0.0001$ \\
\hline C. perfringens & $23.84(665)$ & $19.58(65)$ & $23.73(526)$ & $30.83(74)$ & 0.75 \\
\hline C. coli & $14.88(415)$ & $17.17(57)$ & $15.25(338)$ & $8.3(20)$ & $<.0001$ \\
\hline Feline parvovirus & $7.49(209)$ & $5.72(19)$ & $7.76(172)$ & $7.5(18)$ & 0.28 \\
\hline T.foetus & $6.7(187)$ & $7.23(24)$ & $6.9(153)$ & $4.17(10)$ & 0.015 \\
\hline EPEC & $4.7(131)$ & $7.53(25)$ & $4.19(93)$ & $5.42(13)$ & 0.0029 \\
\hline Giardia lamblia & $4.52(126)$ & $4.82(16)$ & $4.83(107)$ & $1.25(3)$ & 0.0036 \\
\hline ETEC & $2.62(73)$ & $3.31(11)$ & $2.21(49)$ & $5.42(13)$ & 0.06 \\
\hline C. jejuni & $1.76(49)$ & $2.11(7)$ & $1.71(38)$ & $1.67(4)$ & 0.54 \\
\hline EHEC & $1(28)$ & $0(0)$ & $1.08(24)$ & $1.67(4)$ & 0.19 \\
\hline Group A Rotavirus & $0.79(22)$ & $0(0)$ & $0.9(20)$ & $0.84(2)$ & 0.24 \\
\hline C.parvum & $0.75(21)$ & $0.3(1)$ & $0.81(18)$ & $0.84(2)$ & 0.6 \\
\hline C. cayetanensis & $0.68(19)$ & $0.3(1)$ & $0.72(16)$ & $0.84(2)$ & 0.75 \\
\hline EIEC & $0.36(10)$ & $0(0)$ & $0.32(7)$ & $1.25(3)$ & 0.12 \\
\hline Salmonella spp. & $0.25(7)$ & $0.3(1)$ & $0.27(6)$ & $0(0)$ & 0.62 \\
\hline E. histolytica & $0.11(3)$ & $0(0)$ & $0.13(3)$ & $0(0)$ & 0.66 \\
\hline Toxocara cati & $0.07(2)$ & $0.3(1)$ & $0.05(1)$ & $0(0)$ & 0.18 \\
\hline Toxoplasma gondii & $0.07(2)$ & $0(0)$ & $0.09(2)$ & $0(0)$ & 0.76 \\
\hline FIV & $0.04(1)$ & $0(0)$ & $0.05(1)$ & $0(0)$ & 0.88 \\
\hline Total & 100 (2789) & $100(332)$ & $100(2217)$ & $100(240)$ & \\
\hline
\end{tabular}

C. perfringens Clostridium perfringens, C. coli Campylobacter coli, T. foetus Tritrichomonas foetus, EPEC enteropathogenic Escherichia coli, ETEC enterotoxigenic Escherichia coli, C. jejuni Campylobacter jejuni, EHEC enterohemorrhagic Escherichia coli, C. parvum Cryptosporidium parvum, C. cayetanensis Cyclospora cayartensis, EIEC enteroinvasive Escherichia coli, E. histolytica Entamoeba histolytica, FIV feline immunodeficiency virus

The prevalence of each enteropathogen between age groups was compared statistically using the Chi-square test. ${ }^{*} P<0.05$

\section{Seasonal prevalence of feline enteropathogens}

There were differences in seasonal prevalence only in bacterial and viral infections $(P=0.01$ and 0.04 , respectively; Fig. 1A) but not in protozoal infections. Bacterial infections showed the lowest prevalence in April, while viral and protozoal infections showed the lowest prevalence in May. Bacterial infections showed a high prevalence in October, viral infections showed a high prevalence in November, and protozoal infections showed a high prevalence in August. FECV, Clostridium perfringens, and $C$. coli were detected at high rates throughout the year (Fig. 1B). The infection rates of Clostridium perfringens, FPV, EPEC, ETEC, and EHEC changed significantly according to the month.

\section{Association between feline enteropathogens and age}

RT-PCR results showed that the percentages of positive and negative infections were $82.59 \%$ (1338) and $17.41 \%$ (282), respectively. Among positive infections, each individual was infected with 1-6 pathogens at the same time; single, double, triple, quadruple, quintuple, and sextuple infection rates were $29.51 \%$ (478), $27.96 \%$ (453), $16.17 \%$ (262), $6.98 \%$ (113), $1.54 \%$ (25), and $0.43 \%$
(7), respectively (Fig. 2A). The percentages of positive infections in the early age, intermediate age, and old age groups were $11.21 \%$ (150), $78.77 \%$ (1054), and $10.01 \%$ (134), respectively. Across all three age groups, bacterial infections were most common (Fig. 2B). The infection rates of viruses and protozoa were different according to age $(P=0.0006$ and 0.0009 , respectively).

\section{Association between feline enteropathogens and infection patterns}

Among the cases evaluated, 35.72\% (478), 9.87\% (132), and $54.41 \%$ (728) were single infections, mixed infections, and co-infections, respectively. Co-infection was the most common among all groups (Fig. 2C). Among single infections, 48.75\% (233) were bacterial infections, $46.44 \%$ (222) were viral infections, and $4.81 \%$ (23) were protozoan infections (Table 3). Similar to the total prevalence, feline enteric coronavirus (FECV), Clostridium perfringens, and C. coli were the most common pathogens causing single infections. The infection patterns of mixed infections are shown in Fig. 3. Bacterial-bacterial infections accounted for $77.14 \%$ (108) of cases, whereas viral-viral and protozoal-protozoal infections accounted for $22.14 \%$ (31) and $0.71 \%$ (1) of the cases, 


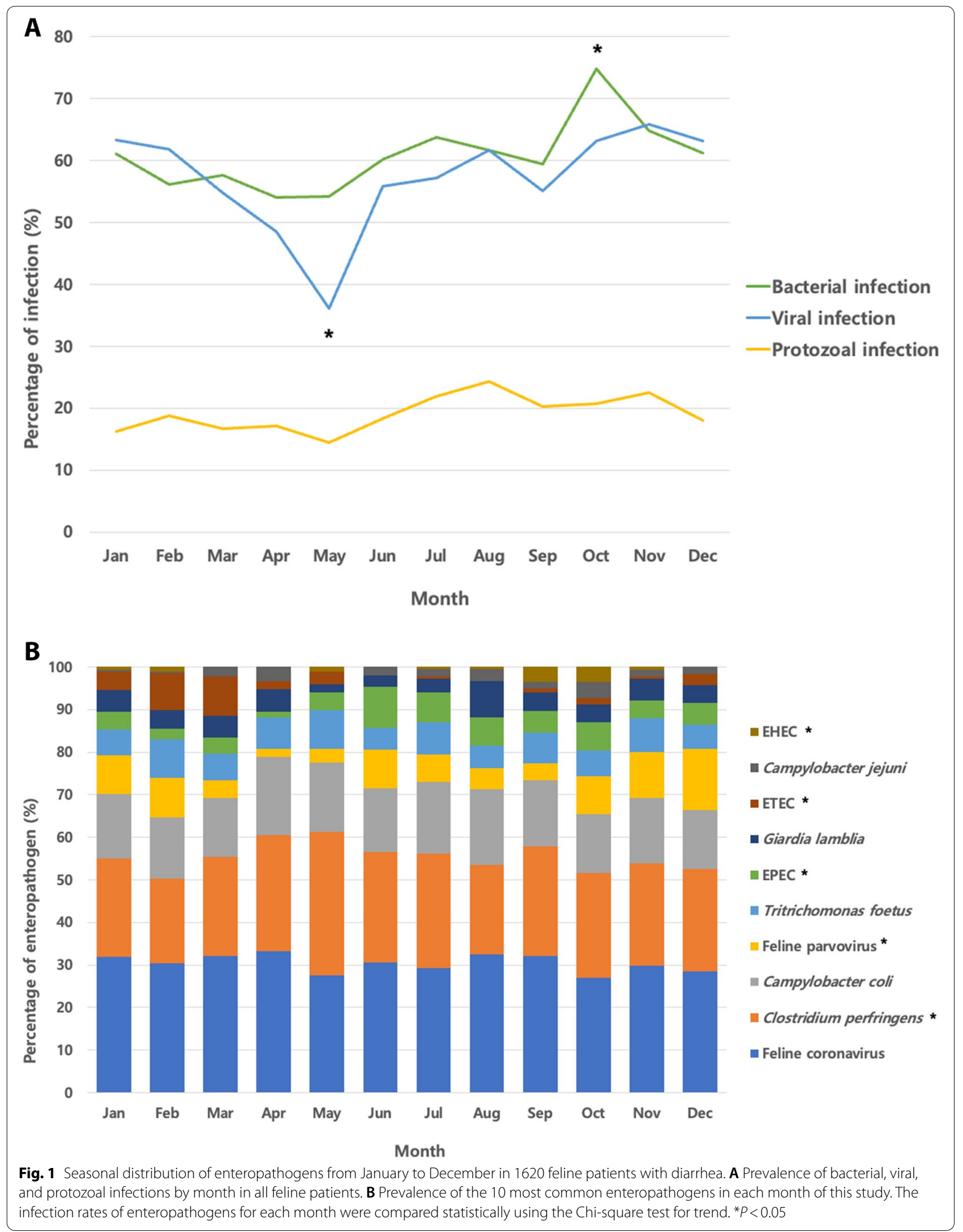


respectively. Among mixed infections, the combination infection rate of Clostridium perfringens and C. coli was high. Co-infections included bacterial-viral (B-V) infections, bacterial-protozoal (B-P) infections, viral-protozoal (V-P) infections, and bacterial-viral-protozoal (B-V-P) infections. B-V infections accounted for the largest proportion $(60.36 \%$; 437). The next highest proportions were B-V-P infections $(25 \%$; 181$)$, V-P infections $(9.12 \% ; 66)$, and B-P infections (5.52\%; 40; Fig. 4A-D). The most common combinations in each group were Clostridium perfringens and FECV (28.38\%) in the B-V pattern, Clostridium perfringens and T. foetus (22.5\%) in the B-P pattern, FECV and T. foetus (43.94\%) in the V-P pattern, and Clostridium perfringens, FECV, and T. foetus (14.92\%) in the B-V-P pattern.

\section{Discussion}

In this study, we evaluated the prevalence, clinical features, and seasonality of feline enteropathogens in the Republic of Korea. This is the first large-scale study to evaluate the clinical features and prevalence of 19 feline enteropathogens using real-time RT-PCR in the Republic of Korea. Most of the diarrheic cats in our study were diagnosed with enteropathogens, with FECV, Clostridium perfringens, Campylobacter spp., E. coli, and FPV being the more common pathogens isolated from the stool of diarrheic cats. These findings are similar to the results of previous studies $[1,3$, $4,11,12]$, but differed somewhat from previous studies. The discrepancies could be related to a variety of factors, such as differences in methodologies, regions, living environments, and concurrent diseases, thereby affecting the species and prevalence of the identified enteropathogens. Bacterial infections were predominant, although the most common enteropathogen in this study was FECV. Notably, bacterial infections peaked in October, viral infections peaked in November, and protozoal infections peaked in August. Viral and protozoal infections showed differences in prevalence according to feline age. When the infection patterns were investigated, the ratios for single infections, mixed infections, and co-infections were 35.72, 9.87, and $54.41 \%$, respectively. FECV was the predominant among single infections, and the most common infection patterns were a combination of Clostridium perfringens and C. coli in mixed infections and a combination of Clostridium perfringens and FECV in co-infections.

FECV was frequently identified in this study. Because FECV is ubiquitous and mostly subclinical, this study might have also had a high proportion of subclinical
FECV infections [34]. In our study, however, the threshold cycle $\left(C_{T}\right)$ value was used to quantify the viral load to determine whether the infection was positive. FECV showed the highest prevalence among single infections, and the $C_{T}$ value and viral load were correlated in realtime PCR [35]. Therefore, FECV is a major pathogen to consider for the diagnosis of infectious feline diarrhea.

Clostridium perfringens is a predominant microorganism in the feces of most carnivores [18, 36]. Because Clostridium perfringens is a normal inhabitant of the intestines of cats that do not have diarrhea [34], PCR analysis of Clostridium perfringens is difficult when attempting to determine whether this organism is the causative agent of diarrhea. $\alpha$-Toxin expressed by Clostridium perfringens was detected in this study. Enterotoxins, rather than Clostridium perfringens itself, can cause enteritis, and our findings are based on the results of DNA amplification of $\alpha$-toxin [18]. Previous studies have shown that $\alpha$-toxin from Clostridium perfringens was only detected in fecal samples from diarrheic cats and not that from asymptomatic cats [12, 36]; however, opposing results have also been reported [1]. Thus, further studies are needed to determine whether Clostridium perfringens is a cause of diarrhea.

Campylobacter spp. is the main cause of infectious diarrhea in cats $[37,38]$, and it showed the third highest prevalence among all organisms in our study. In previous studies, Campylobacter spp. was detected in both diarrheic and healthy cats $[39,40]$, and the prevalence of Campylobacter spp. in diarrheic cats was higher than that in clinically healthy cats [41]. However, in some studies, similar rates have been detected in healthy cats $[39,40$, 42], supporting the possibility of subclinical infection. Alternatively, these discrepancies may be related to differences in test methods, which include bacterial culture, enzyme-linked immunosorbent assay, and PCR. Campylobacter helveticus, Campylobacter upsaliensis, and C. jejuni are also frequently detected in cats [39]. Because $C$. coli and $C$. jejuni are the most common pathogens owing to their thermophilic characteristics [20], we evaluated these two pathogens as a PCR panel [38]. In contrast to previous studies in cats, dogs, and humans, in which $C$. jejuni was found to be a predominant bacterium, our results demonstrated that $C$. jejuni was less frequent than C.coli [41, 43, 44]. The prevalence of Campylobacter spp. may vary according to species, age, underlying disease, season, region, and concurrent infection, which

(See figure on next page.)

Fig. 2 Frequency of detection of multiple enteropathogens in 1620 fecal specimens based on feline patient age. A Comparison of the number of enteropathogens simultaneously detected based on patient age. B Comparison of the number of bacterial, viral, and protozoal enteropathogens based on patient age. $\mathbf{C}$ Comparison of infection type based on patient age. The infection rates of enteropathogen between age groups were compared statistically using the Chi-square test. ${ }^{*} P<0.05$ 


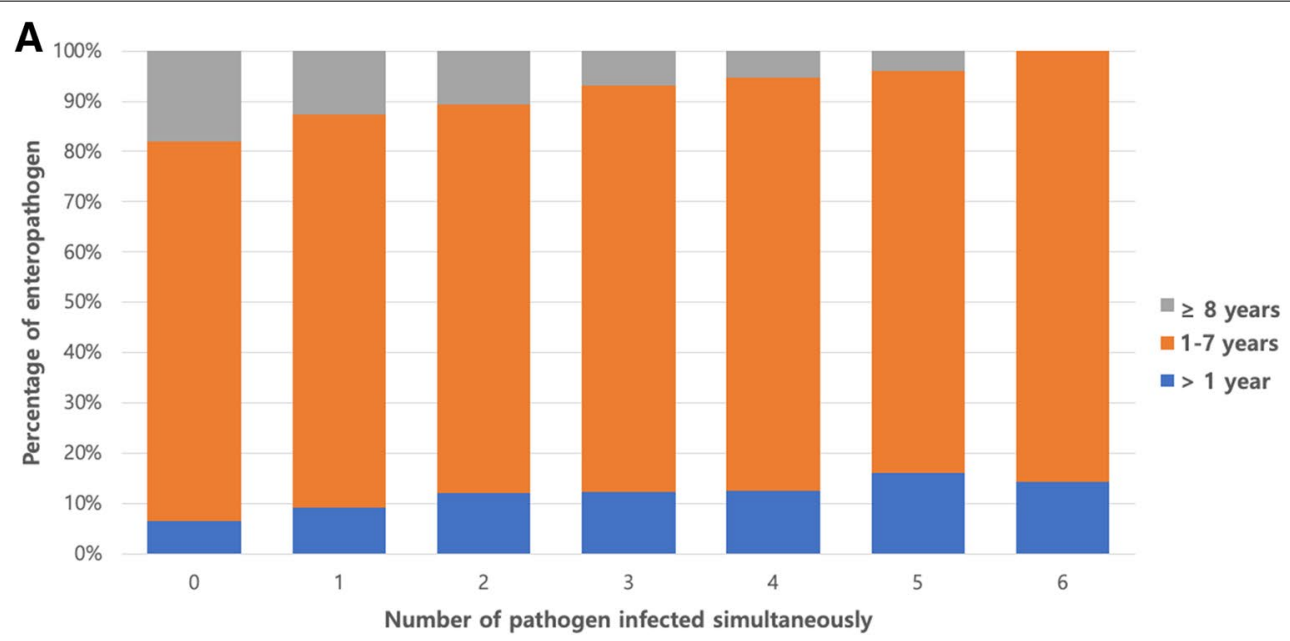

B

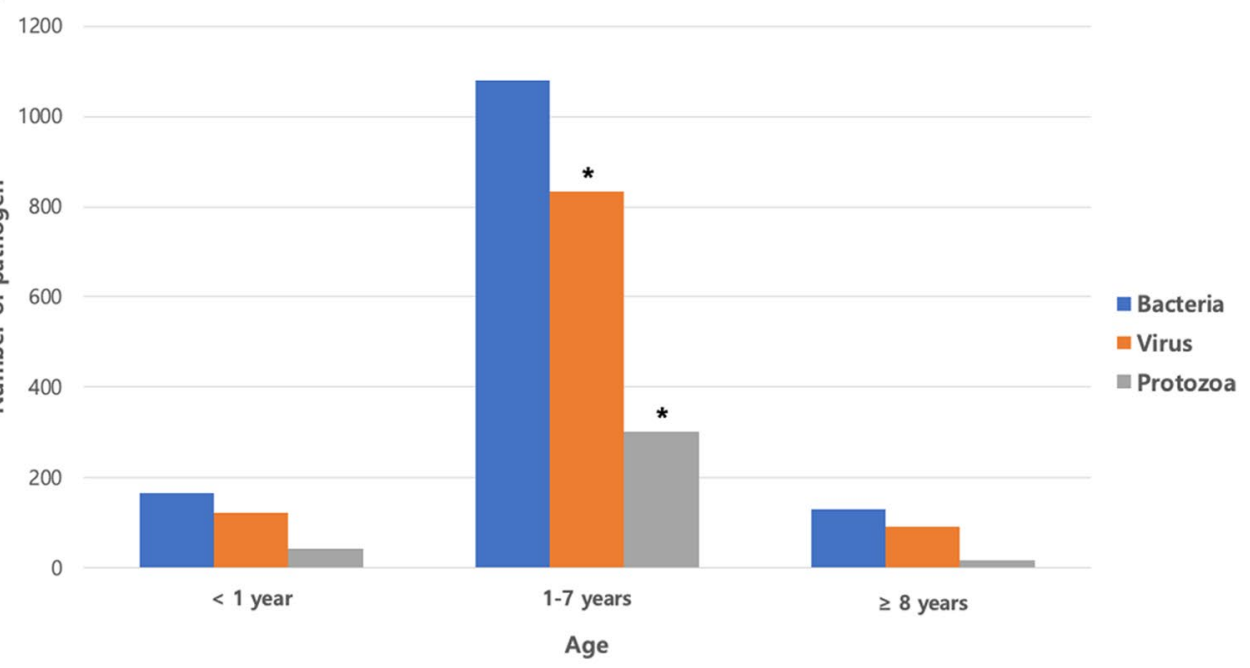

C

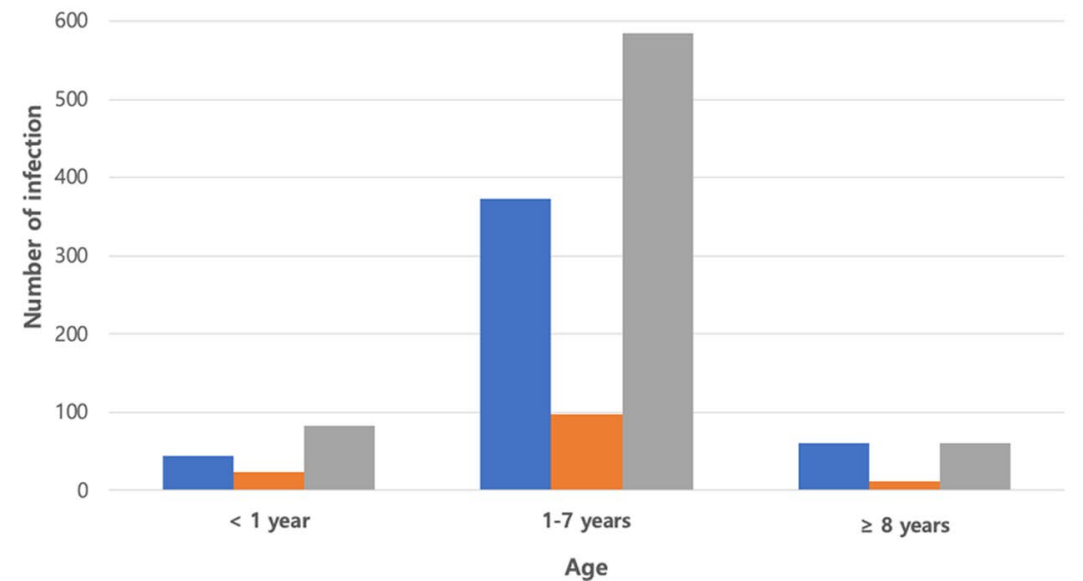

- Single infection Mixed infection Co-infection

Fig. 2 (See legend on previous page.) 
Table 3 Prevalence and infection patterns of enteropathogens from fecal specimens in cats with diarrhea

\begin{tabular}{|c|c|c|c|}
\hline \multirow[t]{2}{*}{ Pathogen } & \multicolumn{3}{|c|}{ Prevalence of pathogen $\%(n)$} \\
\hline & Single infection & Mixed infection & Co-infection \\
\hline Feline coronavirus & $39.33(188)$ & $11.27(31)$ & $29.47(600)$ \\
\hline C.perfringens & $26.78(128)$ & $32.73(90)$ & $21.95(447)$ \\
\hline C. coli & $12.76(61)$ & $22.18(61)$ & $14.39(293)$ \\
\hline Feline parvovirus & $7.11(34)$ & $8.36(23)$ & $7.47(152)$ \\
\hline T. foetus & $2.3(11)$ & $0.36(1)$ & $8.6(175)$ \\
\hline EPEC & $3.77(18)$ & $10.18(28)$ & $4.17(85)$ \\
\hline Giardia lamblia & $1.46(7)$ & $0.37(1)$ & $5.8(118)$ \\
\hline ETEC & $3.14(15)$ & $5.81(16)$ & $2.06(42)$ \\
\hline C. jejuni & $1.26(6)$ & $3.27(9)$ & $1.67(34)$ \\
\hline EHEC & $0.42(2)$ & $1.45(4)$ & $1.08(22)$ \\
\hline Group A Rotavirus & $0(0)$ & $2.55(7)$ & $0.69(14)$ \\
\hline C.parvum & $0.42(2)$ & $0(0)$ & $0.98(20)$ \\
\hline C. cayetanensis & $0.42(2)$ & $0(0)$ & $0.83(17)$ \\
\hline EIEC & $0.42(2)$ & $0.73(2)$ & $0.29(6)$ \\
\hline Salmonella spp. & $0.21(1)$ & $0.37(1)$ & $0.25(5)$ \\
\hline E. histolytica & $0.21(1)$ & $0(0)$ & $0.1(2)$ \\
\hline Toxocara cati & $0(0)$ & $0(0)$ & $0.1(2)$ \\
\hline Toxoplasma gondii & $0(0)$ & $0(0)$ & $0.1(2)$ \\
\hline FIV & $0(0)$ & $0.37(1)$ & $0(0)$ \\
\hline Total & $100(478)$ & $100(275)$ & $100(2036)$ \\
\hline
\end{tabular}

C. perfringens Clostridium perfringens, C. coli Campylobacter coli, T. foetus Tritrichomonas foetus, EPEC enteropathogenic Escherichia coli, ETEC enterotoxigenic Escherichia coli, C. jejuni Campylobacter jejuni, EHEC enterohemorrhagic Escherichia coli, C. parvum Cryptosporidium parvum, C. cayetanensis Cyclospora cayartensis, EIEC enteroinvasive Escherichia coli, E. histolytica Entamoeba histolytica, FIV feline immunodeficiency virus

could explain the higher rates of $C$. coli $[20,45]$. However, because the results of this study were different from those of previous studies, further investigation on subspecies in feline campylobacteriosis is needed.

E. coli is a well-known colonic microorganism, and its pathogenicity depends on various virulence factors [18]. Among known diarrheagenic E. coli in cats, our study showed decreased prevalence in the order of EPEC > ETEC > EHEC > enteroinvasive E. coli (EIEC). When combined altogether, the prevalence of $E$. coli was the fourth most common. EPEC was the most abundant subtype among $E$. coli in our study, consistent with a previous report [46]. However, few studies have reported fecal detection of ETEC, EHEC, and EIEC in diarrheic cats, and EPEC and EHEC are known to also be present in healthy cats.

FPV is a pathogen that is included in the core vaccination schedule for cats [47]. In this study, we did not know the recent vaccine status of the enrolled cats; therefore, it is possible that false-positive results were obtained in individuals who had recently received modified live-virus vaccines [18]. In our study, because the prevalence of FPV was higher in the intermediate and old age groups than in the early age group, the possibility of subclinical infection due to young age was low.

T. foetus and G. lamblia were the most common protozoal infections in this study, similar to previous reports [48]. T. foetus infection is an emerging gastrointestinal disease in cats [49]. Although T. foetus is not a member of the microflora, this organism was detected in fecal samples in cats with or without diarrhea [50]. The pathogenesis of $T$. foetus-associated diarrhea in cats is not fully known [51]. To date, chronically infected cats have remained in clinical remission; however, diarrhea recurs because of food changes or stress [52]. Although subclinical infection is common for G. lamblia, clinical symptoms are also common because of its high infectivity, particularly in kittens and catteries. G. lamblia is a potential zoonotic protozoan that infects most mammals and causes diarrhea [34]. Although subclinical infections are often encountered, even if the test result is positive for G. lamblia, veterinarians should pay close attention to hygiene when handling these cats.

In our study, the feline immunodeficiency virus (FIV) was detected in only one cat. This cat was in the intermediate age group and presented as a mixed infection with FECV. It is possible that the intestinal microflora was infected by FIV. The relationship between FIV infection and various other enteropathogens has not yet been elucidated.

The seasonal distribution of the infection may vary according to the pathogen species. In our study, we analyzed the seasonality of the 10 most prevalent enteropathogens, as well as the seasonality of infection by species type: bacterial, viral, or protozoal. Bacterial and viral infections showed significant differences in prevalence according to the month, whereas protozoal infections did not. In veterinary medicine, few studies have evaluated seasonality by infection type $[43,53]$. In our study, Clostridium perfringens, FPV, EPEC, ETEC, and EHEC showed significant differences in prevalence according to the time of year. Infections from FECV and Campylobacter spp., the most commonly identified pathogens in our study, occurred evenly throughout the year with no seasonality, as in previous studies [43]. In contrast, infection by Campylobacter spp. is more frequent in the summer and fall in cats [53]. However, it is difficult to conclude the clinical significance of these results. We only revealed the descriptive data of every month. Because there are few similar studies in veterinary medicine, making comparisons with the results of our study is difficult. Second, since this study was conducted locally, it is difficult to represent the infection in other regions. Third, these are the results of testing by only one diagnostic laboratory; 


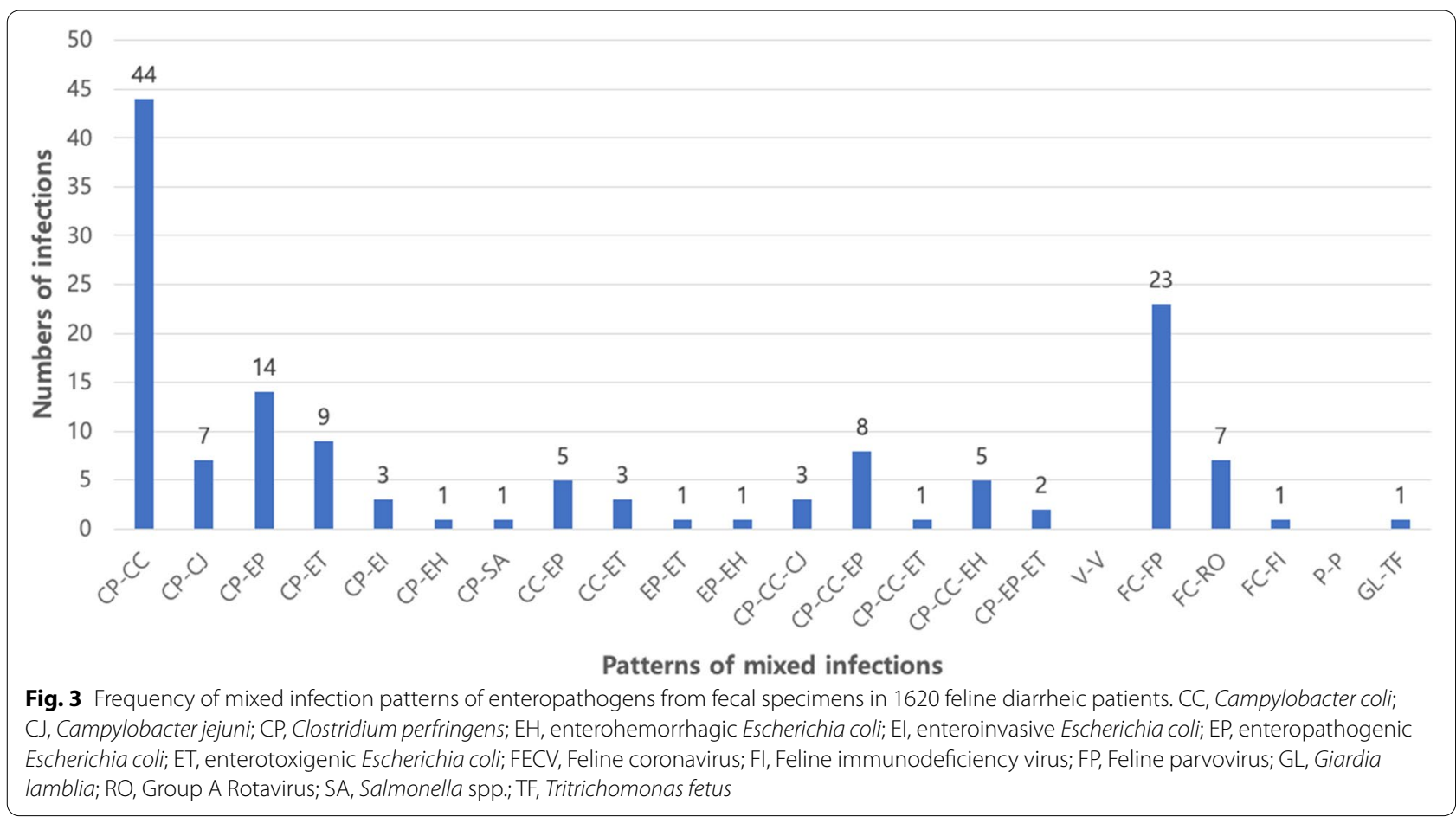

hence, if we combine these with the test results of another diagnostic laboratory, other infection patterns may be observed. In a previous human study, climate, the biological properties of pathogens, and people's eating habits could affect the seasonality of infectious diarrhea [13]. Additional long-term, large-scale studies of seasonality are needed in feline infectious diarrhea.

Some pathogens are more common in felines of certain ages [37, 49, 54]. In our study, there were differences in prevalence according to feline age for FECV, $C$. coli, T. foetus, and EPEC. EIEC, FECV, C. coli, and EPEC were more prevalent in the early age group. In kittens, the prevalence of pathogens is higher because kittens have lower antibody formation than adult cats $[18,50]$. For example, FECV-associated diarrhea is most likely to occur in young kittens [18]. In our study, the prevalence of FECV (31.33\%) was highest in cats under 1 year of age. Other studies have reported higher Campylobacter spp. prevalence rates in cats under 1 year of age [39, 41, 43]. In contrast, $C$. jejuni showed no differences in prevalence according to age, whereas $C$. coli differed among the age groups. EPEC also showed the highest prevalence in the early age group (7.53\%), whereas EIEC and ETEC showed the highest prevalence in the old age group (1.25 and $5.42 \%$, respectively). To date, studies on the relationships between the prevalence of enteropathogens and the age of cats are limited in cats with $E$. coli-associated diarrhea. However, in this study, the prevalence of G. lamblia was higher in the early age group (4.82\%) and the intermediate age group $(4.83 \%)$ than in the old age group $(1.25 \%)$. G. lamblia and T. foetus had significantly higher prevalence rates in cats under 1 year of age than in older cats [5]. In contrast, in our study, the prevalence of T. foetus was not associated with age. Additionally, the proportion of Clostridium perfringens was significantly higher in the old age group, similar to a previous study demonstrating higher fecal concentrations of bacteria in cats over 9 years old [55]. However, because the number of cats in each age group was not balanced, this might affect the results of this study. The results should be interpreted

(See figure on next page.)

Fig. 4 Frequency of co-infection patterns of enteropathogens from fecal specimens in 1620 feline diarrheic patients. A Type of bacterial-viral co-infection. B Type of bacterial-protozoal co-infection. C Type of viral-protozoal co-infection. D Type of bacterial-viral-protozoal co-infection. CC, Campylobacter coli; CJ, Campylobacter jejuni; CP, Clostridium perfringen; CR, Cryptosporidium parvum; CY, Cyclospora cayartensis; EH, enterohemorrhagic Escherichia coli; El, enteroinvasive Escherichia coli; EP, enteropathogenic Escherichia coli, ET, enterotoxigenic Escherichia coli; FECV, Feline coronavirus; FI, Feline immunodeficiency virus; FP, Feline parvovirus; GL, Giardia lamblia; RO, Group A Rotavirus; SA, Salmonella spp.; TF, Toxocara felis; TG, Toxoplasma gondii; TT, Tritrichomonas fetus 
A

Bacteria-virus type

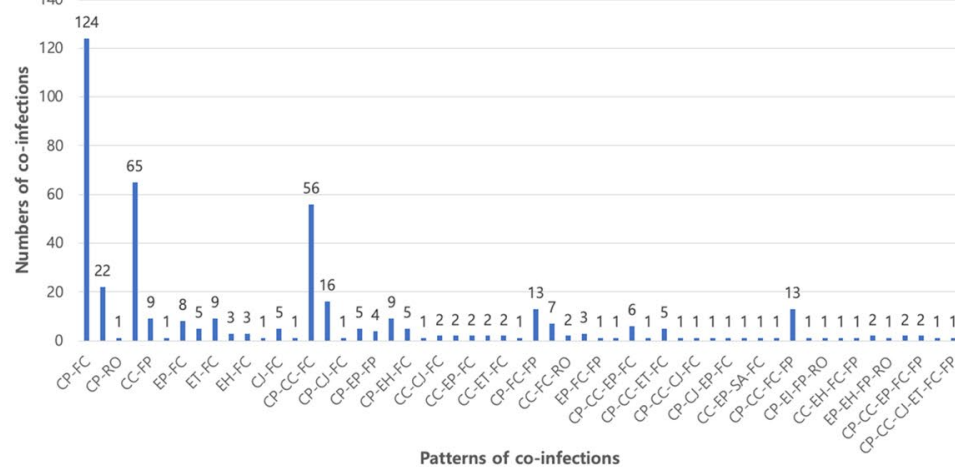

B

Bacteria-protozoa type
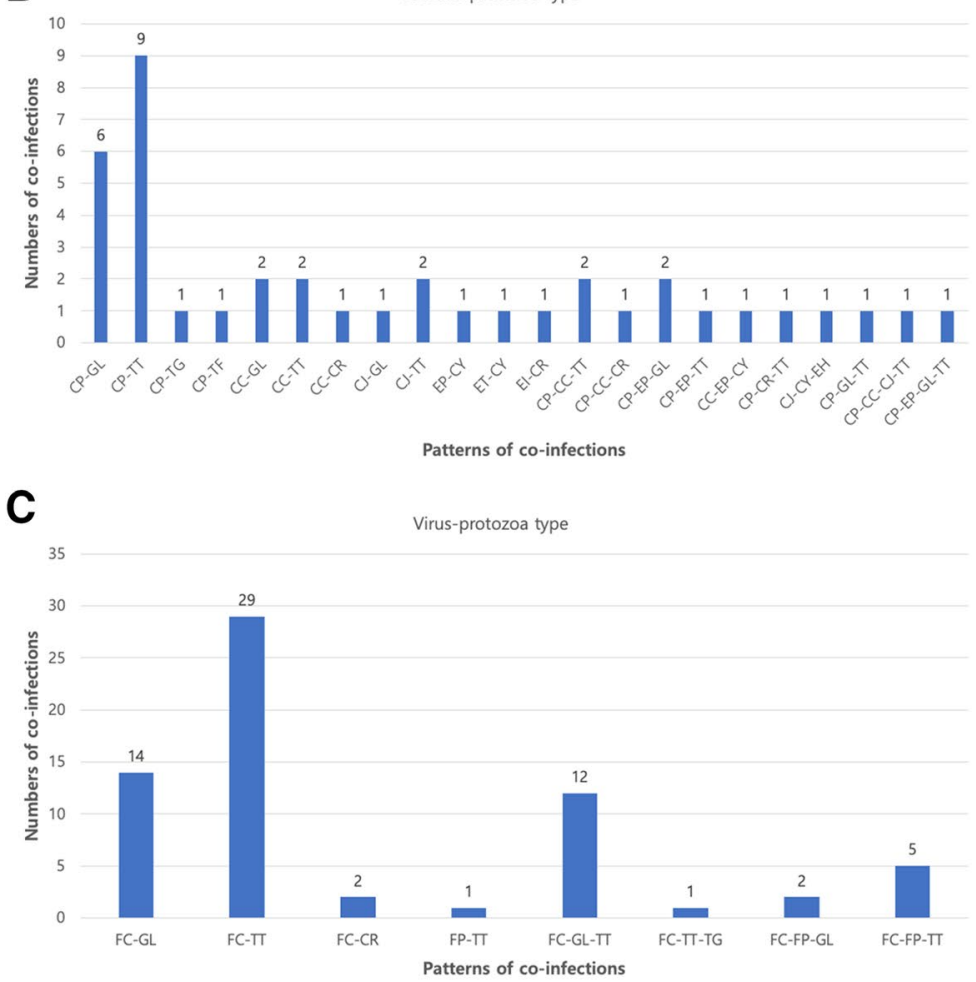

D

Bacteria-virus-protozoa type

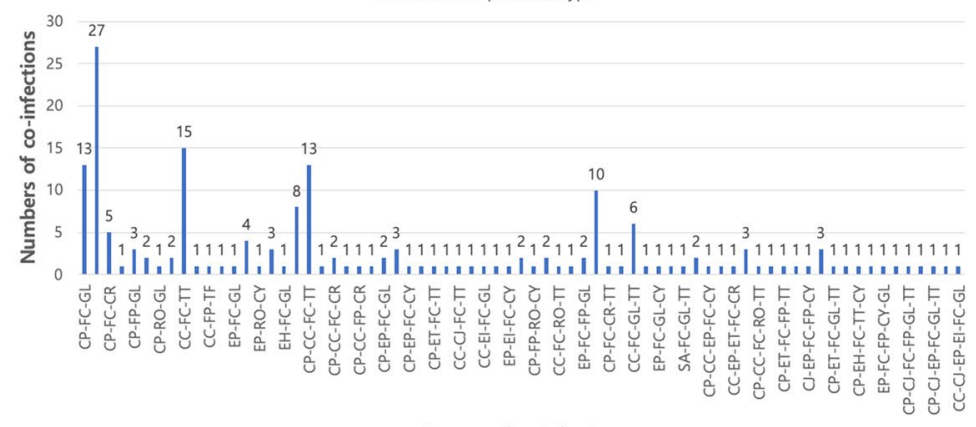

Patterns of co-infections

Fig. 4 (See legend on previous page.) 
in consideration of this point. Further study is needed to ensure that the number of cats in each age group is balanced.

The percentage of multiple infections in our study was $64.28 \%$, which was higher than that in a previous study (44\%) [1]. Concurrent infection with other pathogens can increase the severity of symptoms in some cats because of the possibility of sharing pathogenesis and symbiotic relationships [5, 18], e.g., co-infection with FPV and Salmonella spp. [56]. Fluctuations in the intestinal microbiota may cause second and third infections [57]. In this study, combination infection with Clostridium perfringens plus $C$. coli was predominant in mixed infections. Co-infections were also commonly detected as Clostridium perfringens plus FECV and C. coli plus FECV. Although the prevalence of protozoal infections was lower than that of bacterial and viral infections, such infections play important roles in infection patterns. In cats positive for T. foetus, an increased severity of diarrhea is associated with the presence of Cryptosporidium [58]. Giardia and Cryptosporidium are also interdependent [59]. Our findings are similar to previous findings demonstrating that co-infection-associated protozoa were primarily Giardia and T. foetus [8, 57, 60-62].

Of the 19 pathogens examined in this study, all enteropathogens had zoonotic potential, except FECV, FPV, FIV, and C. cayetanensis, and their combined prevalence was $63.1 \%$. Zoonotic enteropathogens can be transmitted through animal fecal matter and direct contact with the animal [63]. Thus, immunosuppression in the owners or veterinary staff could increase the risk of infection; information regarding the zoonotic potential of these organisms should be provided to owners or veterinary staff. Emerging zoonotic enteropathogens, which are a problem in humans, include Salmonella spp., Campylobacter spp., C. coli, and C. jejuni, with the latter two being the most common in human acute gastrointestinal disease $[21,64]$. The prevalence of Salmonella spp. infection in cats with diarrhea was very low $(0.25 \%)$ in this study, but has been reported to be as high as $6 \%$ in previous studies [1]. Although the prevalence of Salmonella spp. in this study was low, some cases have shown transmission from cats to humans [65, 66]. Similarly, a pet cat has also been reported as a source of transmission of EHEC infection to its owner [67]. In addition, because it is an important zoonotic pathogen, the fact that Salmonella spp. and EHEC were identified in even a small percentage of cat feces is important in terms of public hygiene; this coinfection should be carefully monitored.

There are some limitations to this study. First, it was difficult to conclude that the pathogens detected in this study were the cause of feline diarrhea. Some pathogens found in this study are also detected in healthy cats [1, 4]. Our study did not compare the results between diarrheic and asymptomatic cats. In addition, because this study was conducted using only stool samples and clinical information from patients from various animal hospitals, it is unclear whether the actual cause of diarrhea was the primary infection. Second, it was not possible to confirm whether antibiotics were used immediately before the test. The use of antibiotics might have influenced the results of this study. Third, this study was conducted retrospectively by extracting the results of a test commissioned by a commercial laboratory. Therefore, fecal collection methods may not have been consistent or followed properly, resulting in potential cross-contamination. However, because the laboratory specified the collection method in advance, the possibility of cross-contamination was very low. Finally, in this study, the detection of enteropathogens was performed only by real-time PCR. This method shows the highest sensitivity among laboratory tests, including enzyme-linked immunosorbent assays, bacterial culture, and virus isolation. However, it can lead to false-positive results because of the ability to detect pathogens in carriers $[18,68]$. It is not possible to determine whether a specific organism is the cause of diarrhea based only on real-time PCR. To minimize this possibility, we considered the pathogen to be the causative agent of diarrhea only when the $C_{T}$ value was less than 40 .

\section{Conclusion}

This study suggests that determining the etiology and clinical features of feline infectious diarrhea will facilitate decision making concerning treatments for infectious diarrhea and will help to prevent the spread of infection. Further studies and continuous monitoring are necessary to establish clinical information on various feline enteropathogens in diarrheic cats.

\section{Abbreviations}

FECV: Feline enteric coronavirus; PCR: Polymerase chain reaction; FPV: Feline parvovirus; EPEC: Enteropathogenic E. coli; ETEC: Enterotoxigenic E. coli; EHEC: Enterohemorrhagic E. coli; RT: Reverse transcription; EIEC: Enteroinvasive E. coli; FIV: Feline immunodeficiency virus.

\section{Acknowledgments \\ None.}

\section{Authors' contributions}

$\mathrm{YIO}$ contributed to conceptualization, investigation, statistical analysis, writingoriginal draft and supervision; KWS and DHK contributed to writing-review and editing; DSC contributed to conceptualization, investigation, writing-review and editing and supervision; All authors have read and approved the manuscript.

\section{Funding}

This work was supported by the Korea Institute of Planning and Evaluation for Technology in Food, Agriculture, Forestry (IPET) through the Agri-food R\&D 
Performance Follow-up Support Program funded by the Ministry of Agriculture, Food and Rural Affairs (MAFRA) (818013-02-2-WT011).

\section{Availability of data and materials}

The datasets analysed and the materials used for this study are available from the corresponding author upon reasonable request.

\section{Declarations}

Ethics approval and consent to participate

Not applicable, retrospective records review.

\section{Consent for publication}

Not applicable.

\section{Competing interests}

The authors declare that they have no competing interests.

\section{Author details}

${ }^{1}$ Laboratory of Veterinary Internal Medicine, College of Veterinary Medicine, Seoul National University, Seoul 08826, Republic of Korea. ${ }^{2}$ Knotus Inc., Incheon 22014, Republic of Korea. ${ }^{3}$ Postbio Inc., Guri-si 11906, Republic of Korea.

Received: 14 June 2021 Accepted: 25 October 2021

Published online: 01 December 2021

\section{References}

1. Sabshin SJ, Levy JK, Tupler T, Tucker SJ, Greiner EC, Leutenegger CM Enteropathogens identified in cats entering a Florida animal shelter with normal feces or diarrhea. J Am Vet Med Assoc. 2012;241:331-7.

2. Arsevska E, Singleton D, Sánchez-Vizcaíno F, Williams N, Jones PH, Smyth S, et al. Small animal disease surveillance: Gl disease and salmonellosis. Vet Rec. 2017;181:228-32.

3. Queen E, Marks SL, Farver TB. Prevalence of selected bacterial and parasitic agents in feces from diarrheic and healthy control cats from Northern California. J Vet Intern Med. 2012;26:54-60.

4. Gow AG, Gow DJ, Hall EJ, Langton D, Clarke C, Papasouliotis K. Prevalence of potentially pathogenic enteric organisms in clinically healthy kittens in the UK. J Feline Med Surg. 2009;11:655-62.

5. Paris JK, Wills S, Balzer H-J, Shaw DJ, Gunn-Moore DA. Enteropathogen co-infection in UK cats with diarrhoea. BMC Vet Res. 2014;10:13.

6. Yao C, Köster LS. Tritrichomonas foetus infection, a cause of chronic diarrhea in the domestic cat. Vet Res. 2015;46:35.

7. Setyo L, Donahoe SL, Šlapeta J. Fulminant Tritrichomonas foetus 'feline genotype' infection in a 3-month old kitten associated with viral coinfection. Vet Parasitol. 2019;267:17-20.

8. Kingsbury D, Marks S, Cave N, Grahn RA. Identification of Tritrichomonas foetus and Giardia spp. infection in pedigree show cats in New Zealand. N Z Vet J. 2010;58:6-10.

9. Zanzani SA, Gazzonis AL, Scarpa P, Olivieri E, Balzer H, Manfredi MT. Coinfection with Tritrichomonas foetus and Giardia duodenalis in two cats with chronic diarrhea. Case Rep Vet Med. 2016;2016:5705168.

10. Vasco K, Graham JP, Trueba G. Detection of zoonotic enteropathogens in children and domestic animals in a semirural community in Ecuador. Appl Environ Microbiol. 2016;82:4218-24.

11. Hill SL, Cheney JM, Taton-Allen GF, Reif JS, Bruns C, Lappin MR. Prevalence of enteric zoonotic organisms in cats. J Am Vet Med Assoc. 2000;216:687-92.

12. Andersen L, Levy J, McManus C, McGorray SP, Leutenegger CM, Piccione J, et al. Prevalence of enteropathogens in cats with and without diarrhea in four different management models for unowned cats in the Southeast United States. Vet J. 2018;236:49-55.

13. Gong XH, Wu HY, Li J, Xiao WJ, Zhang X, Chen M, et al. Epidemiology, aetiology and seasonality of infectious diarrhoea in adult outpatients through active surveillance in Shanghai, China, 2012-2016: a crosssectional study. BMJ Open. 2018;8:e019699.
14. Chao DL, Roose A, Roh M, Kotloff K, Proctor JL. The seasonality of diarrheal pathogens: a retrospective study of seven sites over three years. BioRxiv. 2019;2019:541581.

15. Hamilton KW, Cifu AS. Diagnosis and management of infectious diarrhea. JAMA. 2019:321:891-2.

16. Kim NO, Jung SM, Na HY, Chung GT, Yoo CK, Seong WK, et al. Enteric bacteria isolated from diarrheal patients in Korea in 2014. Osong Public Health Res Perspect. 2015;6:233-40.

17. Chi CY, Liao LN, Ho CM, Chou CH, Ho MW, Wang JH. Epidemiology, clinical features, and microbiology of patients with diarrhea in community clinics in Taiwan. J Microbiol Immunol Infect. 2018;51:527-34.

18. Greene CE. Infectious diseases of the dog and cat. 4th ed. St. Louis: Elsevier; 2013.

19. Tuzio H, Edwards D, Elston T, Evans L, Glaser C, Gulledge ML, et al. Feline zoonoses guidelines from the American Association of Feline Practitioners. J Feline Med Surg. 2005;7:243-74.

20. Marks SL, Rankin S, Byrne BA, Weese JS. Enteropathogenic bacteria in dogs and cats: diagnosis, epidemiology, treatment, and control. J Vet Intern Med. 2011;25:1195-208.

21. Chomel B. Emerging and re-emerging zoonoses of dogs and cats. Animals. 2014:4:434-45.

22. Ma M, Ohtani K, Shimizu T, Misawa N. Detection of a group II intron without an open reading frame in the alpha-toxin gene of Clostridium perfringens isolated from a broiler chicken. J Bacteriol. 2007;189:1633-40.

23. Antikainen J, Kantele A, Pakkanen SH, Laaveri T, Riutta J, Vaara M, et al. A quantitative polymerase chain reaction assay for rapid detection of 9 pathogens directly from stools of travelers with diarrhea. Clin Gastroenterol Hepatol. 2013;11:1300-7.

24. Kim JS, Jang JI, Eom JS, Oh CH, Kim HG, Kim BH, et al. Molecular characterization of the InvE regulator in the secretion of type III secretion translocases in Salmonella enterica serovar Typhimurium. Microbiology. 2013;159:446-61.

25. Liu J, Gratz J, Amour C, Kibiki G, Becker S, Janaki L, et al. A laboratorydeveloped TaqMan array card for simultaneous detection of 19 enteropathogens. J Clin Microbiol. 2013;51:472-80.

26. Benetka V, Kubber-Heiss A, Kolodziejek J, Nowotny N, Hofmann-Parisot M, Mostl K. Prevalence of feline coronavirus types I and II in cats with histopathologically verified feline infectious peritonitis. Vet Microbiol. 2004;99:31-42.

27. Streck AF, Ruster $D$, Truyen $U$, Homeier T. An updated TaqMan real-time PCR for canine and feline parvoviruses. J Virol Methods. 2013;193:6-8.

28. Wilkes RP, Kani SA, Tsai YL, Lee PA, Chang H, Ma LJ, et al. Rapid and sensitive detection of feline immunodeficiency virus using an insulated isothermal PCR-based assay with a point-of-need PCR detection platform. J Vet Diagn Investig. 2015;27:510-5.

29. Yao C. Diagnosis of Tritrichomonas foetus-infected bulls, and ultimate approach to eradicate bovine trichomoniasis in US cattle? J Med Microbiol. 2013;62:1-9.

30. Durant J, Irenge LM, Fogt-Wyrwas R, Dumont C, Doucet J, Mignon B, et al. Duplex quantitative real-time PCR assay for the detection and discrimination of the eggs of Toxocara canis and Toxocara cati (Nematoda, Ascaridoidea) in soil and fecal samples. Parasit Vectors. 2012;5:288.

31. Lin MH, Chen TC, Kuo TT, Tseng CC, Tseng CP. Real-time PCR for quantitative detection for toxoplasma gondii. J Clin Microbiol. 2000;38:4121-5.

32. Varma M, Hester JD, Schaefer FW 3rd, Ware MW, Alan Lindquist HD. Detection of Cyclospora cayetanensis using a quantitative real-time PCR assay. J Microbiol Methods. 2003;53:27-36.

33. Harb A, Abraham S, Rusdi B, Laird T, O’Dea M, Habib I. Molecular detection and epidemiological features of selected bacterial, viral, and parasitic enteropathogens in stool specimens from children with acute diarrhea in Thi-Qar Governorate, Iraq. Int J Environ Res Public Health. 2019;16:1573.

34. Cook AK. Feline infectious diarrhea. Topics Companion Anim Med. 2008;23:169-76.

35. Decaro N, Pratelli A, Campolo M, Elia G, Martella V, Tempesta M, et al. Quantitation of canine coronavirus RNA in the faeces of dogs by TaqMan RT-PCR. J Virol Methods. 2004:119:145-50.

36. Papasouliotis K, Sparkes A, Werrett G, et al. Assessment of the bacterial flora of the proximal part of the small intestine in healthy cats, and the effect of sample collection method. Am J Vet Res. 1998;59:48-51.

37. Acke E. Campylobacteriosis in dogs and cats: a review. N Z Vet J. 2018:66:221-8. 
38. Bojanić K, Midwinter AC, Marshall JC, Rogers LE, Biggs PJ, Acke E. Variation in the limit-of-detection of the ProSpecT Campylobacter microplate enzyme immunoassay in stools spiked with emerging Campylobacter species. J Micrbiol Methods. 2016;127:236-41.

39. Giacomelli M, Follador N, Coppola L, Martini M, Piccirillo A. Survey of Campylobacter spp. in owned and unowned dogs and cats in northern Italy. Vet J. 2015;204:333-7.

40. Parsons B, Porter C, Ryvar R, Stavisky J, Williams NJ, Pinchbeck GL, et al. Prevalence of Campylobacter spp. in a cross-sectional study of dogs attending veterinary practices in the UK and risk indicators associated with shedding. Vet J. 2010;184:66-70.

41. Pölzler T, Stüger HP, Lassnig H. Prevalence of most common human pathogenic Campylobacter spp. in dogs and cats in Styria, Austria. Vet Med Sci. 2018;4:115-25

42. Rossi M, Hänninen M, Revez J, Hannula M, Zanoni RG. Occurrence and species level diagnostics of Campylobacter spp., enteric Helicobacter spp. and Anaerobiospirillum spp. in healthy and diarrheic dogs and cats. Vet Microbiol. 2008;129:304-14.

43. Torkan S, Vazirian B, Khamesipour F, Dida GO. Prevalence of thermotolerant Campylobacter species in dogs and cats in Iran. Vet Med Sci. 2018;4:296-303.

44. Andrzejewska M, Szczepańska B, Klawe J, Spica D, Chudzinska M. Prevalence of Campylobacter jejuni and Campylobacter coli species in cats and dogs from Bydgoszcz (Poland) region. Pol J Vet Sci. 2013;16:115-20.

45. Acke E, McGill K, Golden O, Jones BR, Fanning S, Whyte P. Prevalence of thermophilic Campylobacter species in household cats and dogs in Ireland. Vet Rec. 2009;164:44-7.

46. Morato E, Leomil L, Beutin L, Krause G, Moura RA, Pestana de Castro AF. Domestic cats constitute a natural reservoir of human enteropathogenic Escherichia coli types. Zoonoses Public Health. 2009;56:229-37.

47. Day M, Horzinek M, Schultz R, Vaccination Guidelines Group of the World Small Animal Veterinary Association. Guidelines for the vaccination of dogs and cats compiled by the vaccination guidelines group (VGG) of the world small animal veterinary association (WSAVA). J Small Anim Pract. 2016:57:E1-E45.

48. Polak K, Levy J, Crawford P, Leutenegger CM, Moriello KA. Infectious diseases in large-scale cat hoarding investigations. Vet J. 2014;201:189-95.

49. Bastos BF, Almeida FM, Brener B. What is known about Tritrichomonas foetus infection in cats? Rev Bras Parasitol Vet. 2019;28:1-11.

50. Holliday M, Deni D, Gunn-Moore DA. Tritrichomonas foetus infection in cats with diarrhoea in a rescue colony in Italy. J Feline Med Surg. 2009;11:131-4.

51. Tolbert M, Gookin J. Mechanisms of Tritrichomonas foetus pathogenicity in cats with insights from venereal trichomonosis. J Vet Intern Med. 2016;30:516-26.

52. Foster DM, Gookin JL, Poore MF, Stebbins ME, Levy MG. Outcome of cats with diarrhea and Tritrichomonas foetus infection. J Am Vet Med Assoc. 2004;225:888-92.

53. Bender JB, Shulman SA, Averbeck GA, Pantlin GC, Stromberg BE. Epidemiologic features of Campylobacter infection among cats in the upper midwestern United States. J Am Vet Med Assoc. 2005;226:544-7.

54. Shim JO, Chang JY, Kim A, Shin S. Different age distribution between campylobacteriosis and nontyphoidal salmonellosis in hospitalized Korean children with acute inflammatory diarrhea. J Korean Med Sci. 2017;32:1202-6.

55. Patil A, Rayner L, Carrion P. Effect of age on fecal microflora of cats. In proceedings of the 2003 nestle purina nutrition forum. Suppl Compend Contin Educ Pract Vet. 2004;26:60.

56. Foley JE, Orgad U, Hirsh DC, Poland A, Pedersen NC. Outbreak of fatal salmonellosis in cats following use of a high-titer modified-live panleukopenia virus vaccine. J Am Vet Med Assoc. 1999;214:67-70 43-44.

57. Bissett SA, Stone ML, Malik R, Norris JM, O'Brien C, Mansfield CS, et al. Observed occurrence of Tritrichomonas foetus and other enteric parasites in Australian cattery and shelter cats. J Feline Med Surg. 2009;11:803-7.

58. Gookin JL, Levy MG, Law JM, Papich MG, Poore MF, Breitschwerdt EB. Experimental infection of cats with Tritrichomonas foetus. Am J Vet Res. 2001;62:1690-7.

59. Keith CL, Radecki SV, Lappin MR. Evaluation of fenbendazole for treatment of Giardia infection in cats concurrently infected with Cryptosporidium parvum. Am J Vet Res. 2003;64:1027-9.
60. Bell ET, Gowan RA, Lingard AE, McCoy RJ, Slapete J, Malik R. Naturally occurring Tritrichomonas foetus infections in Australian cats: 38 cases. J Feline Med Surg. 2010;12:889-98.

61. Kuehner KA, Marks SL, Kass PH, Sauter-Louis C, Grahn RA, Barutzki D, et al. Tritrichomonas foetus infection in purebred cats in Germany: prevalence of clinical signs and the role of co-infection with other enteroparasites. J Feline Med Surg. 2011;13:251-8.

62. Stockdale HD, Givens MD, Dykstra CC, Blagburn BL. Tritrichomonas foetus infections in surveyed pet cats. Vet Parasitol. 2009;160:13-7.

63. Zambrano LD, Levy K, Menezes NP, Freeman MC. Human diarrhea infections associated with domestic animal husbandry: a systematic review and meta-analysis. Trans R Soc Trop Med Hyg. 2014;108:313-25.

64. Lee MD, Newell DG. Campylobacter in poultry: filling an ecological niche. Avian Dis. 2006:50:1-9.

65. Wright JG, Tengelsen LA, Smith KE, Bender JB, Frank RK, Grendon JH, et al. Multidrug-resistant Salmonella Typhimurium in four animal facilities. Emerg Infect Dis. 2005;11:1235.

66. Tauni M, Österlund A. Outbreak of Salmonella typhimurium in cats and humans associated with infection in wild birds. J Small Anim Pract. 2000;41:339-41.

67. Busch U, Hörmansdorfer S, Schranner S, Huber I, Bogner K, Sing A. Enterohemorrhagic Escherichia coli excretion by child and her cat. Emerg Infect Dis. 2007;13:348.

68. leven M. Currently used nucleic acid amplification tests for the detection of viruses and atypicals in acute respiratory infections. J Clin Virol. 2007:40:259-76.

\section{Publisher's Note}

Springer Nature remains neutral with regard to jurisdictional claims in published maps and institutional affiliations.

Ready to submit your research? Choose BMC and benefit from:

- fast, convenient online submission

- thorough peer review by experienced researchers in your field

- rapid publication on acceptance

- support for research data, including large and complex data types

- gold Open Access which fosters wider collaboration and increased citations

- maximum visibility for your research: over $100 \mathrm{M}$ website views per year

At BMC, research is always in progress.

Learn more biomedcentral.com/submissions 